\title{
The Analysis of the Understanding Levels of Teacher Candidates in Different Departments about Basic Astronomy Concepts
}

\author{
Ümmü Gülsüm DURUKAN* \\ Elementary Science Education, Giresun University, Giresun, Turkey
}

Ayşegül SAĞLAM-ARSLAN

Secondary Science and Mathematics Education, Karadeniz Technical University, Trabzon, Turkey.

\begin{tabular}{ll}
\hline \hline Article history & Learners face a variety of concepts during the instructional process \\
Received: & they experience. These concepts are mostly introduced by teachers; \\
& thus, the competences of teachers in terms of teaching concepts are \\
Received in revised form: & vitally important. The aim of this study is to detect the \\
09.05 .2015 & understanding levels of teacher candidates about basic astronomy \\
& concepts. The method of the study was a survey method. The \\
11.05 .2015 & sample of the study was composed of 293 teacher candidates from \\
Key words: & early childhood teacher education, primary school teacher \\
\hline Astronomy concepts, Earth, & education, elementary science education and physics education \\
understanding levels. & departments. The data were collected by the achievement test, \\
& which included three questions intended to help describe, draw and \\
& explain the movement. The data were analysed by using the two \\
& different understanding levels in the literature. The data obtained \\
& showed that the teacher candidates could not submit proper \\
& explanations for the concepts: the Earth, the Sun, the Moon, \\
& planets, stars and satellites. This situation can be interpreted as an \\
& indicator that teacher candidates did not have enough information \\
& about the basic astronomy concepts. When the departments were \\
& compared with respect to the understanding levels, it can be said \\
& that teacher candidates from elementary science teacher education \\
& and physics teacher education departments were at a better level of \\
& understanding than their counterparts in early childhood teacher \\
& education and elementary teacher education departments. We must \\
& ensure that candidates are aware of their deficiencies and for these \\
deficiencies to be eliminated we present various opportunities & about astronomy activities like finding the Sun and a star using \\
& Stellarium program for the candidates to help develop themselves. \\
\hline \hline
\end{tabular}

*Elementary Science Education, Faculty of Education, Giresun University, 28100, Giresun, Turkey,
Tel:0454-3101274, e-mail: u.g.durukan@ gmail.com 


\section{Introduction}

Astronomy is one of the disciplines of science which humans have taken an interest in since the first ages and have conducted various studies on. It has begun to gain a place in instructional research, since it took its place in education programs. We encounter astronomy topics in almost every level of the instructional process in Turkey, so teaching astronomy has an importance, both in primary and secondary education, and in the institutions which train teachers (Küçüközer, Bostan \&Iş1ldak, 2010). Percy (1998) mentioned the importance of teaching astronomy topics and stated that there were really important astronomy practises in our daily life. The author said the study of astronomy was beneficial because it included, not only experimental methods, but also a dimension related to observation. Moreover, it was asserted that astronomy is a science which teaches the individuals to think effectively, both correctly and logically (Tunca, 2005).

When the studies related to astronomy in the literature were analysed, these studies could be grouped into four headings to determine the perceptions of the participants representing different groups (students, teacher candidates, and teachers) about: (1) finding alternative concepts about basic astronomy topics and concepts (Klein, 1982; Atwood \& Atwood, 1996, 1997; Kikas, 2005; Kalkan \& Kıroğlu, 2007; Cin, 2007; Emrahoğlu \& Öztürk, 2009; Frede, 2006; Kallery, 2011; Wallace, Prather \& Duncan, 2011, 2012; Kurnaz, 2012; Durukan \& Sağlam-Arslan, 2013; Taşcan, 2013); (2) applying conceptual change processes about basic astronomy topics and concepts (Callison \& Wright, 1993; Ercan, Taşdere \& Ercan, 2010; Trundle, Atwood \& Christopher, 2002, 2006, 2007; Trumper, 2006a; Küçüközer, Bostan \& Işıldak 2010; Şahin, Bülbül \& Durukan, 2013); (3) determining mental models basic astronomy topics and concepts (Vosniadou \& Brewer, 1992; Liu, 2003; Panagiotaki, Nobes \& Potton, 2008; Straatemeier, Van der Mass \& Jansen, 2008; İyibil \& Sağlam-Arslan, 2010) and (4) applying learning progression basic astronomy topics and concepts (Plummer, 2014). The researches, which was aimed at understanding the perceptions of the participants related to astronomy concepts, revealed that the participants usually did not acquire knowledge at an adequate level (Barba \& Rubba, 1992; Summers \& Mant, 1995; Atwood \& Atwood, 1996, 1997; Suzuki, 2003; Frede, 2006; Kalkan \& Kıroğlu, 2007; Emrahoğlu \& Öztürk, 2009); however, there were a small number of studies which aimed at correcting the lack of knowledge and misconceptions (Küçüközer et al., 2010; Trumper, 2006a; Ercan et al., 2010).

\section{The Importance and Purpose of the Study}

Students encounter many concepts and subjects in different levels from primary education to higher education throughout the formal education process, which lasts 12 years on average in Turkey, and they acquire knowledge related to these concepts and subjects. In this process, teachers play a vital role in bringing the subjects into the classroom environment and helping the students to reach the desired learning outcomes. The ability of the teachers to perform their duties is closely related to their professional qualities and qualifications (Erden, 2005). These qualities are comprised of: general knowledge, content knowledge and professional knowledge and skills (Erden, 2005). Therefore, the teachers' content knowledge is very important because teachers are in a position to affect the educational life of their students (Karal, 2003). In other words, when the teacher's content knowledge is inadequate, this situation is reflected in their students. As the studies of Karal (2003) has emphasised, academic achievement and student performance depend on the teacher.

Many studies carried out in the field of astronomy education and teaching have investigated the knowledge of teacher candidates about astronomy concepts, and/or their understanding 
levels of these concepts (Barba \& Rubba, 1992; Summers \& Mant, 1995; Atwood \& Atwood, 1996, 1997; Suzuki, 2003; Frede, 2006; Kalkan \& Kıroğlu, 2007; Emrahoğlu \& Öztürk, 2009), and the effectiveness of the instructional process prepared to correct the lack of knowledge inherent in the teacher candidates (for example; Callison \& Wright, 1993; Trumper, 2001, 2006a, 2006b; Trundle et al., 2002, 2006, 2007; Küçüközer, 2007; Mullholland \& Ginns, 2008; Ercan et al., 2010). These studies generally focused on the same astronomy concepts such as the Earth, Sun and Moon, etc. But there are different concepts for which there are almost no studies like planet, star and satellite. At the same time, the understanding levels of teacher candidates in different fields regarding basic astronomy concepts were not determined; it was revealed that a study is required to be carried out in this context. Moreover, the examination of the knowledge the teacher candidates have acquired will be a reflection of the formal education they have had throughout their educational life and it will also help to determine the deficiencies in this field. As this situation is one of results of the effect of our education system on the individual, it shows the importance of the research from a different viewpoint.

The aim of the study is to determine the understanding levels of the teacher candidates who are studying in different teacher education departments (Physics, Elementary Science, Primary School and Early Childhood Teacher Education) about astronomy concepts and to seek answers for the following research questions:

- What are the understanding levels of basic astronomy concepts by the teacher candidates in different departments?

- How a relation is there between the understanding levels of the teacher candidates on the basic astronomy concepts?

\section{Method}

The study was carried out by survey research, one of the descriptive research methods, which aims at describing the phenomena to be analysed in the best way and to determine the current situation (Çepni, 2007). Because the phenomena to be analysed is described as it is and the study environment is not interfered with during the process (Cohen \& Manion, 1994; Karasar, 2009), this method was thought to be suitable for the environment of the study in the survey method.

\section{Sampling}

The sample of the study was comprised of 293 teacher candidates studying in their final year in an Education Faculty in the departments of early childhood teacher education (74 participants), primary school teacher education (70 participants), elementary science teacher education (87 participants), and physics teacher education (62 participants) in the Eastern Black Sea region of Turkey.

The knowledge and skills which the teacher candidates gained throughout their education life about the field of astronomy can be listed as follows: within the framework of a life-science course under the theme of 'Yesterday, Today, Future', the students learned the concepts of the Earth and the Sun in the 1st grade, the same concepts, their motions and what can see when look up the sky in the 2nd grade, the Moon and its phases, the Earth and its motion and the concepts of the Sun in the 3rd grade (MEB, 2009). Within the framework of a Science and Technology course under the field of the 'Earth and the Universe', the students learned the subjects related to the shape of the Earth and its structural properties in the 4th grade, the size 
of the Earth, the Sun and the Moon and their motions, and they were able to distinguish these concepts from each other in the 5th grade (MEB, 2009). Within the framework of the Science and Technology course, the materials which form the lithosphere, the place and the importance of these materials in our life were studied. In the 7th grade, the students were introduced to the basic concepts, such as galaxy, planet, star, comet, and constellation. They were also introduced to the Solar System and optical instruments used for space exploration. In the 8th grade, the formation of the Earth, plate tectonics, and the climate phenomena in the atmosphere were mentioned and the importance of these events in our daily life was addressed (MEB, 2009). The teacher candidates are expected to comprehend the basic astronomy concepts, which are presented in a spiral structure in teaching curricula, with lifescience and science and technology courses in elementary education (Türkoğlu, Örnek, Gökdere, Süleymanoğlu \& Orbay, 2009).

\section{Data Collection Tool}

An achievement test was developed by the researchers and was used as a data collection tool within the study. While the achievement test was being developed, firstly the teaching programs were examined and then the basic astronomy concepts, which the participants were supposed to know, were determined. The following questions were composed by taking into consideration the concepts which were identified and their features.

(1) Could you explain the concepts given below respectively? You can support your explanations by giving examples.

(2) Earth, Sun, Moon, Planet, Star, Satellite

(3) Could you draw shapes of these celestial bodies?

(4) Do these celestial bodies move? If so, how do you explain the movement of these celestial bodies?

In the first question of the achievement test was asked the participants to identify these concepts. In the second question was asked the teacher candidates do draw the shapes belonging to these concepts. In the third question was asked views the participants about the celestial bodies' movements. In the fourth question, the relationship between the celestial body pairs was determined by the researcher and reasons for the explanation were asked for.

\section{The Validity of the Study}

In order to determine the validity of the achievement test, it was piloted with 21 the mathematics teacher candidates who were studying in the same faculty. We analyzed whether the questions were compatible with the purpose of the research, and whether they were clear and answerable in line with the data obtained. In the pilot study, teacher candidates were asked about the basic features of celestial bodies.. The data obtained showed that more details, such as movement and shape regarding celestial bodies should be asked for, in addition to basic features. Moreover, three physics education experts' views were taken into account regarding the test. In the light of the pilot data and readjustments, we prepared the final version of the achievement test.

\section{Data Analysis}

The understanding levels generated by Abraham, Williamson and Westbrook (1994) would be used in order to determine the conceptual understanding levels, in similar studies in the literature (for example, Çalık \& Ayas, 2005; Sağlam-Arslan \& Devecioğlu-Kaymakçı, 
2010). The following understanding levels were used for the analysis of the definitions of these concepts, and the responses given to the questions about whether these concepts move or not, were included in this study.

Table 1. Understanding levels and explanations used in data analysis for the explanations related to concepts

\begin{tabular}{ll}
\hline Understanding Levels & Explanations \\
\hline [0] No response & $\begin{array}{l}\text { Not responding the question; repeating the question asked; irrelevant responses } \\
\text { Responses such as 'I don't know', 'I don't remember' }\end{array}$ \\
\hline [1] No Understanding & Unscientific responses \\
\hline [2] Partial Understanding & $\begin{array}{l}\text { Short answers; responses consisting of partial scientific knowledge; giving only } \\
\text { examples }\end{array}$ \\
\hline $\begin{array}{l}\text { [3] Restricted } \\
\text { understanding }\end{array}$ & $\begin{array}{l}\text { Incomplete answers, responses containing the one or more aspects of scientific } \\
\text { responses }\end{array}$ \\
\hline [4] Sound Understanding & Scientific responses \\
\hline
\end{tabular}

In Table 2, the following levels, generated by Kara, Erduran-Avcı and Çekbaş (2008) and Uzunkavak (2009), were used for the analysis of the drawings related to basic astronomy concepts.

Table 2. Understanding levels and explanations used in data analysis for the drawings of the shapes related to concepts

\begin{tabular}{ll} 
Understanding Levels & Explanations \\
\hline 0 & No illustration \\
\hline 1 & Wrong illustration \\
\hline 2 & Correct illustration which includes wrong elements \\
\hline 3 & Correct but incomplete illustration (not including error) \\
\hline 4 & Completely correct and complete drawing \\
\hline
\end{tabular}

To ensure the reliability of the results, classification of the teacher candidates' responses according to the understanding levels were checked by another expert studied in this area.

In terms of presentation of the findings and convenience for discussion, the frequencies of the responses of the participants at different understanding levels were taken into account separately, both among the participants studying in the same department and among the participants taking part in the study, and then their percentages were calculated. The participants taking part in the study were coded by taking into consideration the departments (ECTE for early childhood teacher education, PSTE for primary school teacher education, ESTE for elementary science teacher education, and PTE for physics teacher education) and examples from the expressions and drawings of the participants were presented.

The Chi-Square Test be done with SPSS 16.0 program for each of the features of concepts and to determine whether there is significant differences in understanding levels according to their department or not.

\section{Findings}

The findings obtained from the achievement test were presented under four headings after "the concept-concept example" matching was performed. 


\section{Understanding levels related to the planet - the Earth}

Table 4 presents the distribution of responses given by the teacher candidates to the questions asked about the planet and the Earth, in terms of understanding levels.

Table 4. Understanding levels of the responses of the teacher candidates related to the planet and the Earth.

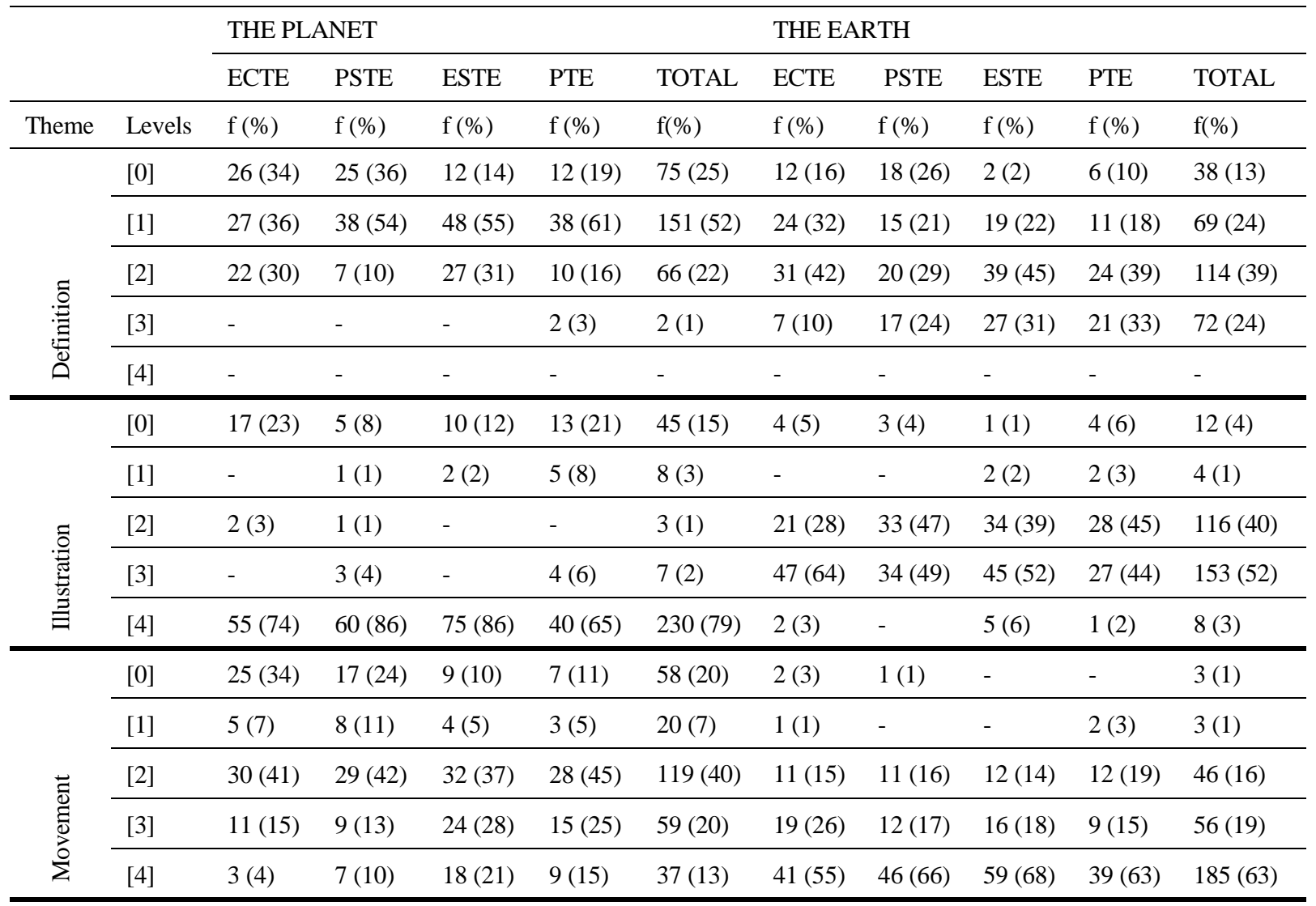

When Table 4 was analysed, it was determined that the responses of the teacher candidates to the question about the definition of the planet were usually at the level of not being able to understand (Level 1,52\%) and to the question about the definition of the Earth was at the level of partial understanding (Level 2,39\%). The teacher candidates usually defined 'the planet' as an object belonging to a system and they gave the celestial bodies as the Earth, Moon, and Mercury, as examples. However, there were teacher candidates, such as PTE35, who made more scientific definitions such as "Planets are massive objects revolving around a star like the Earth. They exist in liquid or gas form". The teacher candidates used the following expressions of "the place which we live in, residence, planet, system" for the Earth, which is an example of the 'planet' concept. The responses such as "the planet where we live" (ECTE17), "the planet which accommodates both living and non-living beings" (PTE55) or "one of the planets which exists in the solar system" (ESTE48) were assessed to be in the partial understanding category, where the majority of responses of the candidates were concentrated. Based on the responses, it can be stated that the teacher candidates thought the 'planet concept' was different kinds of celestial bodies (such as a star or satellite) belonging to the Solar System and they made overgeneralizations for this concept. When the teacher candidates' distribution according to their understanding levels were analysed, it showed variability in terms of the departments where they studied. While $31 \%$ of the teacher candidates were at Level 2 for the question related to the definition of a planet, $31 \%$ of the teacher candidates were at Level 3 for the definition of the Earth. While only $3 \%$ of the 
physics teacher candidates could answer the question related to the definition of a 'planet' at so-called Level 3,33\% of them could answer the question related to the definition of the Earth at Level 3. While $30 \%$ of early childhood teacher candidates and $10 \%$ of primary school teacher candidates were at Level 3 for the question related to the definition of a planet, $10 \%$ of early childhood teacher candidates and $24 \%$ of the elementary teacher candidates were at Level 3 for their definition of the Earth. In this case, it can be stated that elementary science and physics teacher candidates gave more scientific responses than the candidates studying in the other departments. It can be stated that the case determined was related to the courses (particularly the astronomy course) instructed in the department.

It was revealed that $79 \%$ of the teacher candidates did illustrations for the question related to the shape of the planet at the sound understanding level (Level 4) but 52\% of them made illustrations for the question related to the shape of the Earth at the restricted understanding level (Level 3). The candidates drew the Earth only as a round shape or globe. However, although the candidates could not define the planet, the spherical illustrations they made for the shape of the planet held the qualification of correct illustrations. When the distribution of the illustrations in terms of understanding levels was analysed, $86 \%$ of elementary science and primary school teacher candidates were at sound understanding level (Level 4) for the 'planet' concept, but it was revealed that $64 \%$ of early childhood teacher education teacher candidates made illustrations at a more scientific level for the Earth as a concept example. The responses of physics teacher candidates drew attention because their responses were at lower understanding levels, when compared to the teacher candidates studying in other departments. The examples belonging to the illustrations of the participants in terms of their understanding levels are presented in Table 5.

Table 5. Examples from the illustrations of the candidates related to the planet and the Earth

Levels

[1]

[2]

[3]

[4]

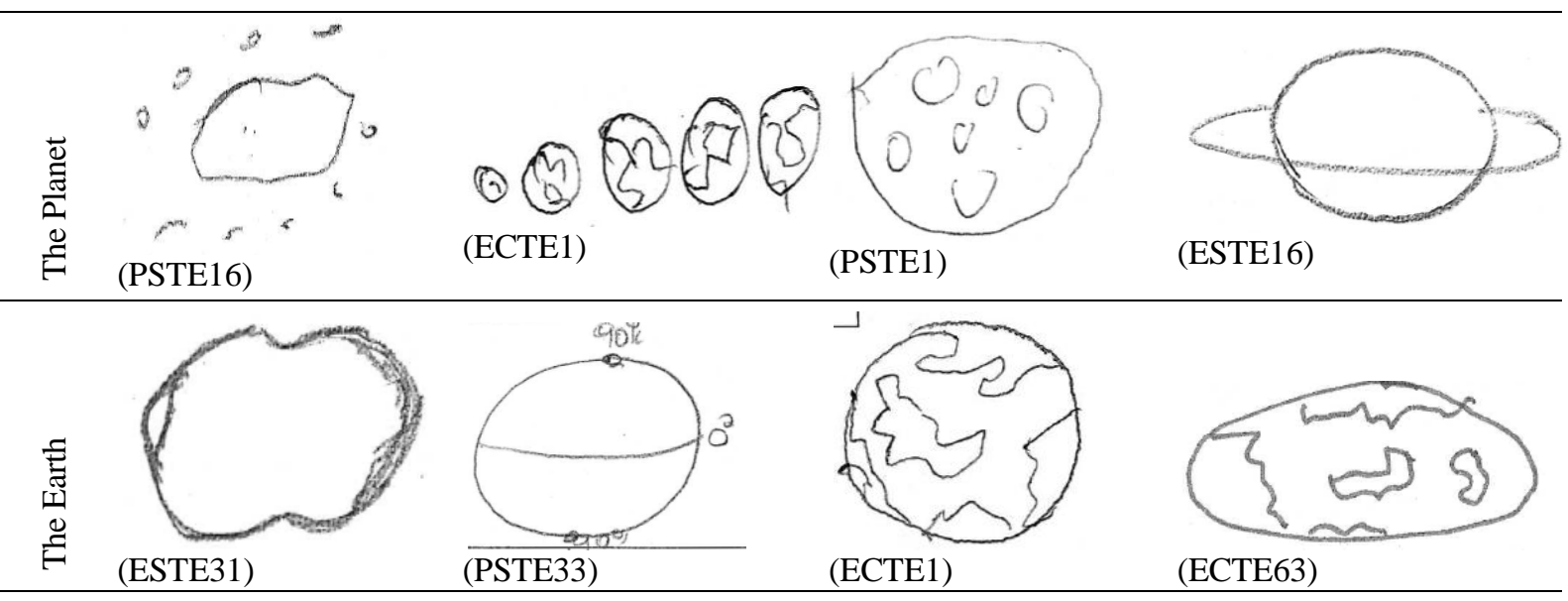

In the question which asked whether the given celestial bodies moved or not and if they were moving, the teacher candidates were asked to explain this movement: $40 \%$ of the teacher candidates were at partial understanding level (Level 2) for the 'planet' concept and $63 \%$ of them were at sound understanding level (Level 4) for the Earth. While these teacher candidates stated that the planet was revolving in an orbit, some teacher candidates determined that the planets did not move, or that they thought that only the Earth out of all the planets moved. The statement of the participant coded as ECTE45 can be given as an example to support this view: "Only the Earth among the planets moves." The teacher candidates 
stated for this question that the Earth rotated by itself and that it also revolved around the Sun. The teacher candidates who answered the movement of the Earth question correctly differed in opinion on topics where they had unscientific knowledge about how the planet moved and if the planet was motionless or if it moved around a specific orbit and they had not acquired the knowledge that the planets rotated by themselves. When the distributions in terms of understanding levels were analysed, there was not a significant difference between the teacher candidates in terms of the departments they study in for this question and the teacher candidates gave responses at the partial understanding level for the 'planet' concept (41\%, $42 \%, 37 \%$, and $45 \%$, respectively) and sound understanding level for the Earth $(55 \%, 66 \%$, $68 \%, 63 \%$, respectively). The emphasis made on the movements of the celestial bodies, and particularly the movements of the Earth, Moon and Sun, which have been included in the astronomy topics of the teaching programs since the primary school level, might be counted as the reason for this case.

When the distribution of the responses in terms of understanding levels were analysed, it could be stated that elementary science teacher candidates made explanations which included more scientific elements when compared to the teacher candidates in the other departments. For example, the explanations made by $21 \%$ of the elementary science teacher candidates about the movements of the planets were at scientific understanding level. Moreover, the concentration of the distribution of the responses related to the Earth, in terms of understanding level, and the distribution of the responses related to the 'planet' concept in terms of understanding level on different levels drew attention. The distribution with the question which required the definition of the Earth and 'planet' can be given as an example. While the definitions of the candidates about the Earth usually took place at "the partial understanding level", their definitions about the 'planet' took place at the level of not understanding. We can reach the conclusion that, although the teacher candidates knew that the Earth is a planet, they answered the questions about our world by taking into consideration the events they experienced in their daily lives (with expressions such as "the Earth is formed from water, stone and soil" (PSTE42)), but they could not make a clear definition and explanation for the 'planet' concept. The findings related to the planet and Earth are presented in Table 7 for the question which asked the teacher candidates to express the relationship between the concept pairs given in the achievement test.

Most of the teacher candidates (71\%) defined 'the star' as a celestial body which radiates the light it gets from various sources (such as the Sun); these definitions are at the level of not understanding. The statements such as "It reflects the light it gets from the Sun. It is the source of light at night" (ECTE10) and "a meteorite which gets light from the Moon and reflects it on the Earth" (PSTE51) can be given as examples to responses at this level.

Table 7. Understanding levels of the responses of the teacher candidates related to the star and Sun

\begin{tabular}{|c|c|c|c|c|c|c|c|c|c|c|c|}
\hline & & \multicolumn{5}{|c|}{ THE STAR } & \multicolumn{5}{|c|}{ THE SUN } \\
\hline & & ECTE & PSTE & ESTE & PTE & TOTAL & ECTE & PSTE & ESTE & PTE & TOTAL \\
\hline $\begin{array}{l}\text { Them } \\
\mathrm{e}\end{array}$ & Level & $f(\%)$ & $f(\%)$ & $\mathrm{f}(\%)$ & $\mathrm{f}(\%)$ & $f(\%)$ & $\mathrm{f}(\%)$ & $\mathrm{f}(\%)$ & $\mathrm{f}(\%)$ & $f(\%)$ & $f(\%)$ \\
\hline \multirow{5}{*}{ 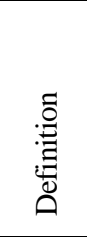 } & [0] & $19(26)$ & $23(3)$ & $11(13)$ & $17(27)$ & $70(24)$ & $10(14)$ & $14(20)$ & $3(3)$ & $4(6)$ & $31(11)$ \\
\hline & [1] & $55(74)$ & $45(64)$ & $69(79)$ & $40(65)$ & $209(71)$ & $57(77)$ & $48(69)$ & $66(76)$ & $38(61)$ & $209(71)$ \\
\hline & [2] & - & $2(3)$ & $6(9)$ & $5(8)$ & $13(4)$ & $7(9)$ & $7(10)$ & $13(15)$ & $15(25)$ & $42(14)$ \\
\hline & [3] & - & - & $1(1)$ & - & $1(1)$ & - & $1(1)$ & $5(6)$ & $5(8)$ & $11(4)$ \\
\hline & [4] & - & - & - & - & - & - & - & - & - & - \\
\hline
\end{tabular}




\begin{tabular}{|c|c|c|c|c|c|c|c|c|c|c|c|}
\hline \multirow{5}{*}{ 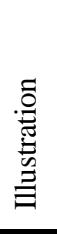 } & {$[0]$} & $8(11)$ & $2(3)$ & $10(11)$ & $13(21)$ & $33(11)$ & $4(5)$ & $2(3)$ & - & $5(8)$ & $11(4)$ \\
\hline & [1] & $60(82)$ & $68(97)$ & $73(84)$ & $45(73)$ & $246(84)$ & $6(8)$ & $10(14)$ & $15(17)$ & $7(11)$ & 38 (13) \\
\hline & [2] & $6(8)$ & - & $4(5)$ & $4(6)$ & $14(5)$ & $64(87)$ & $58(83)$ & $71(82)$ & $50(81)$ & $243(82)$ \\
\hline & [3] & - & - & - & - & - & - & - & $1(1)$ & - & $1(1)$ \\
\hline & [4] & - & - & - & - & - & - & - & - & - & - \\
\hline \multirow{5}{*}{$\begin{array}{l}\overrightarrow{\tilde{D}} \\
\overrightarrow{0} \\
\overrightarrow{0} \\
\vec{\Sigma}\end{array}$} & {$[0]$} & $24(32)$ & $11(16)$ & $20(23)$ & $19(31)$ & $74(25)$ & $12(16)$ & $8(11)$ & $12(14)$ & $10(16)$ & $42(14)$ \\
\hline & [1] & $27(37)$ & $26(37)$ & $25(29)$ & $22(35)$ & $100(34)$ & $47(64)$ & $49(70)$ & $41(47)$ & $25(40)$ & $162(56)$ \\
\hline & [2] & $21(28)$ & $32(46)$ & $35(40)$ & $19(31)$ & $107(36)$ & $9(12)$ & $8(11)$ & $18(21)$ & $10(16)$ & $45(15)$ \\
\hline & [3] & $2(3)$ & $1(1)$ & $6(7)$ & $2(3)$ & $11(4)$ & $6(8)$ & $5(8)$ & $16(18)$ & $17(28)$ & $44(15)$ \\
\hline & [4] & - & - & $1(1)$ & - & $1(1)$ & - & - & - & - & - \\
\hline
\end{tabular}

When the candidates' definitions related with the Sun were examined, it is seen that an important number of the definitions made by the teacher candidates, were such as: "the sun warms us", or is "a system that gives and provides light" or "the source of energy" were at the level of not understanding (Level 1: 71\%). The statement such as "It is the energy source of the system which is formed of planets, stars and such celestial bodies" (ESTE79) can be given as an example of the definitions given by the teacher candidates. The Sun was defined by some teacher candidates as a planet which can be supported with the following statement: "It is a planet which is in space, made up of fire and which we use its light and heat as the source of energy" (ECTE58). With the responses at restricted understanding level (Level 3, 4\%), the statements such as the Sun "is a small star which is the light and heat source for all the planets and satellites in its system. It includes "He and $\mathrm{H}_{2}$ " in its composition" (ESTE30) or "The Sun is our medium-sized star. The Earth revolves around the Sun and the Sun revolves in its own orbit" (PTE35) can be given as examples of the correct responses related to the definition. When the distribution in terms of understanding levels was analysed, it was revealed that the responses, which included scientific elements about the definitions of the Sun and star belonged to elementary science and physics teacher candidates. While $1 \%$ of the teacher candidates were at restricted understanding level for the concept of 'star', $4 \%$ of them were at restricted understanding level for the Sun.

When the distribution of the illustrations of the teacher candidates in terms of understanding level was analysed, the majority of teacher candidates drew shapes which were at not understanding level (Level 1, 84\%) for 'the star' and partial understanding level (Level 2, $82 \%$ ) for the Sun. The teacher candidates depicted the shape of the Sun as spherical but they depicted 'the star' by drawing a pentagram as it is on our Turkish flag. Furthermore, $82 \%$ of early childhood teacher candidates, $97 \%$ of primary school teacher candidates, $84 \%$ of elementary science teacher candidates and $73 \%$ of physics teacher candidates made illustrations at the level of not understanding regarding the question about 'the star' and $87 \%$, $83 \%, 82 \%$ and $81 \%$ of the teacher candidates illustrated the Sun at the level of partial understanding, respectively. A few examples of illustrations by the teacher candidates are presented below, in terms of understanding levels (Table 8). 
Table 8. Examples of illustrations by the teacher candidates for the concepts of 'the star' and the Sun.

Levels

While the responses related to the movement of the 'star' are stuck at the level of not understanding (Level 1,34\%) and partial understanding (Level 2,36\%), the responses related to the movement of the Sun are at the level of not understanding (Level 1,56\%). There were teacher candidates who thought that the stars are fixed, in other words, are motionless, besides the teacher candidates who thought that the stars move. However, they explained the movements of the stars with expressions which included misconceptions, such as: shooting star, falling star and the eclipse of the star. When the teacher candidates were asked to explain the movement of the Sun, it was determined that, while some teacher candidates thought that the Sun was motionless, the rest of the teacher candidates thought that the Sun was moving but they could only explain some movements of the Sun. The statements of the candidates, such as "it revolves around its own axis" (PSTE17), "it moves in the Milky Way galaxy" (ESTE74) or "it revolves around itself, it roams around the Milky Way" (PTE35) can be given as examples. Elementary science and physics teacher candidates made up the majority of the teacher candidates who could explain the movements of the Sun and 'the star'. For example, $18 \%$ of elementary science teacher candidates and $28 \%$ of physics teacher candidates could explain the movement of the Sun at the level of restricted understanding (Level 3). This situation can be explained because the candidates studying in the other departments were not interested in astronomy topics, but also it can be attributed to the teacher candidates' not having knowledge about space, except the solar system. When the distribution of the responses of the teacher candidates related to the departments they were studying in terms of understanding levels were analysed, elementary science and physics teacher candidates could answer the questions at higher understanding levels. Between the responses of the teacher candidates to the questions related to the concept of 'star', the difference which revealed itself in terms of the departments they were studying in occurred at the understanding levels related to the movement of the stars.

The findings related to the concepts of the Sun and 'star' are presented in Table 9 for the question which asks for explanations of the relationship between the concept pairs given to the candidates in the achievement test. 
Table 10. Understanding levels of responses of the teacher candidates related to the satellite and the Moon

\begin{tabular}{|c|c|c|c|c|c|c|c|c|c|c|c|}
\hline & & \multicolumn{5}{|c|}{ THE SATELLITE } & \multicolumn{5}{|c|}{ THE MOON } \\
\hline & & ECTE & PSTE & ESTE & PTE & TOTAL & ECTE & PSTE & ESTE & PTE & TOTAL \\
\hline Theme & Level & $\mathrm{f}(\%)$ & $\mathrm{f}(\%)$ & $f(\%)$ & $\mathrm{f}(\%)$ & $f(\%)$ & $\mathrm{f}(\%)$ & $f(\%)$ & $f(\%)$ & $\mathrm{f}(\%)$ & $f(\%)$ \\
\hline \multirow{5}{*}{ 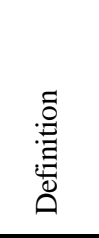 } & {$[0]$} & $38(51)$ & $39(56)$ & $26(30)$ & $25(40)$ & $128(43)$ & $12(16)$ & $19(27)$ & $4(5)$ & $5(8)$ & $40(14)$ \\
\hline & {$[1]$} & $5(8)$ & $11(16)$ & $14(16)$ & $10(16)$ & $40(14)$ & $33(45)$ & $8(11)$ & $5(6)$ & $11(18)$ & $57(19)$ \\
\hline & [2] & $27(36)$ & $13(19)$ & $20(23)$ & $10(16)$ & $70(24)$ & $3(4)$ & $1(1)$ & $6(7)$ & $4(6)$ & $14(5)$ \\
\hline & [3] & $4(5)$ & $7(10)$ & $27(31)$ & $15(24)$ & $53(18)$ & $23(31)$ & $37(53)$ & $44(50)$ & $28(45)$ & $132(45)$ \\
\hline & {$[4]$} & - & - & - & $2(3)$ & $2(1)$ & $3(4)$ & $5(8)$ & $28(32)$ & $14(22)$ & $50(17)$ \\
\hline \multirow{5}{*}{ 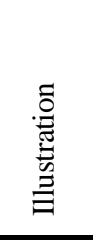 } & {$[0]$} & $27(37)$ & $28(40)$ & $21(24)$ & $20(32)$ & $96(33)$ & $5(7)$ & $2(3)$ & $1(1)$ & $5(8)$ & $13(4)$ \\
\hline & {$[1]$} & $14(19)$ & $13(19)$ & $10(12)$ & $7(11)$ & $44(15)$ & $2(3)$ & - & - & - & $2(1)$ \\
\hline & [2] & $7(9)$ & $1(1)$ & - & $2(3)$ & $10(3)$ & $44(59)$ & $29(42)$ & $18(21)$ & $16(26)$ & $107(37)$ \\
\hline & [3] & - & - & $1(1)$ & $7(11)$ & $8(3)$ & $6(8)$ & $12(17)$ & $22(25)$ & $14(22)$ & $54(18)$ \\
\hline & [4] & $26(35)$ & $28(40)$ & $55(63)$ & $26(42)$ & $135(46)$ & $17(23)$ & $27(38)$ & $46(53)$ & $27(44)$ & $117(40)$ \\
\hline \multirow{5}{*}{$\begin{array}{l}\vec{\Xi} \\
\text { है } \\
\overrightarrow{0} \\
\text { ¿ }\end{array}$} & {$[0]$} & $37(50)$ & $20(29)$ & $18(21)$ & $17(27)$ & $92(30)$ & $15(20)$ & $6(9)$ & $7(8)$ & $6(10)$ & $34(11)$ \\
\hline & {$[1]$} & $2(3)$ & $9(13)$ & $9(10)$ & $4(6)$ & $24(8)$ & $5(7)$ & $7(10)$ & $5(6)$ & $5(8)$ & $22(8)$ \\
\hline & [2] & $25(33)$ & $27(38)$ & $28(32)$ & $23(38)$ & $103(35)$ & $26(35)$ & $24(33)$ & $20(23)$ & $12(19)$ & $82(28)$ \\
\hline & [3] & $2(3)$ & $1(1)$ & $2(2)$ & $1(2)$ & $6(2)$ & $22(30)$ & $20(29)$ & $42(48)$ & $28(45)$ & $112(38)$ \\
\hline & [4] & $8(11)$ & $13(19)$ & $30(35)$ & $17(27)$ & $68(23)$ & $6(8)$ & $13(19)$ & $13(15)$ & $11(18)$ & $43(15)$ \\
\hline
\end{tabular}

When the distribution of the teacher candidates in terms of understanding levels were analysed, elementary science teacher candidates gave responses at higher levels when defining both 'the satellite' (Level 3, 31\%) and the Moon (Level 4, 32\%) but physics teacher candidates gave responses at higher levels when defining only the Moon (Level 4, 22\%). It can be stated that early childhood teacher education and primary school teacher candidates had difficulty in defining the concept of the Moon (Level 0: 51\% and 56\%, respectively). It was found that the responses about the shape of the Moon were usually at the level of sound understanding (Level 4, 46\%) and the responses about the shape of the Moon were usually at the level of partial understanding (Level 2, 37\%) and sound understanding (Level 4, 40\%). When the shape of the satellite was asked to be drawn, the teacher candidates drew either the Moon or the artificial satellites. The teacher candidates usually illustrated the Moon in the shape of a crescent. Very few teacher candidates drew the phases of the Moon for the shape of the Moon. The illustrations belonging to these examples are presented in Table 11.

Table 11. Examples from the drawings of the teacher candidates related to the concepts of 'the satellite' and the Moon.

Levels

[1]

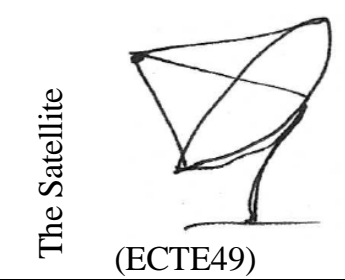

[2]

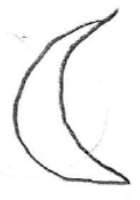

(ECTE29)
[3]

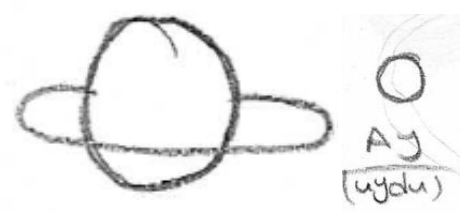

(PTE22)
[4]

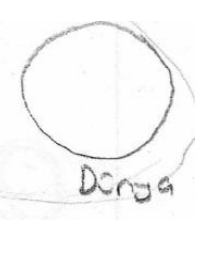




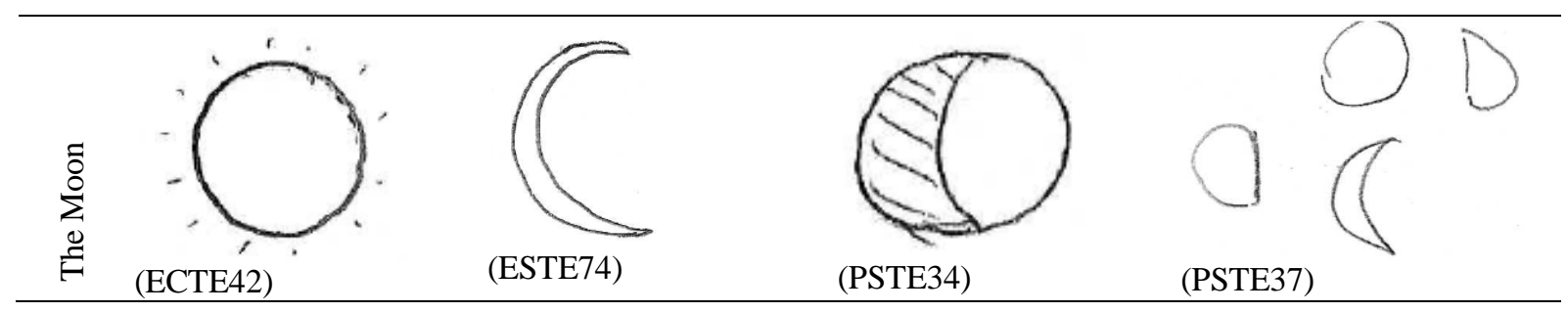

While the teacher candidates were explaining the movements of 'the satellite', they made explanations which were evaluated at different understanding levels. 50\% of the early childhood teacher candidates usually were not able to answer, $38 \%$ of primary school and physics teacher candidates were at the level of partial understanding, and 35\% of elementary science teacher candidates were at the level of sound understanding. It was found that the teacher candidates at the level of partial understanding (Level 2, 35\%) thought that 'the satellite' moved in the orbits. Also, it was found that the teacher candidates at the level of restricted understanding (Level 3,2\%) thought that if the satellite enters the planet's gravitational field, it revolves. When the understanding levels of the teacher candidates related to the movements of the Moon were analysed, early childhood and primary school teacher candidates were at the level of partial understanding (Level 2: 35\%, 33\%, respectively) and elementary science and physics teacher candidates were at the level of restricted understanding (Level 3: 48\%, 45\%, respectively). The teacher candidates stated that the Moon revolves both around the Earth and its own axis and added that the Moon revolves around the Sun indirectly. Some teacher candidates determined that the Moon was motionless but it looks as if it is moving due to the movements of the Earth. These teacher candidates tried to explain their views with statements such as "The Moon does not revolve. The Earth rotates but it stands still" (ECTE68). In this understanding level, while the number of the teacher candidates who pointed out that the Moon revolves around the Earth was more in number; the number of teacher candidates who stated that 'the satellite' revolves around the planet whose gravitational field it enters was few in number. Moreover, while some teacher candidates explained the movements of the Moon around its own axis, there were no teacher candidates who explained the similar movements of 'the satellite'. When the distribution of the teacher candidates in terms of understanding levels was taken into consideration, it was found that elementary science teacher candidates were at higher levels.

Elementary science teacher candidates gave responses to the questions which asked for the definition and movement of 'the satellite' at higher understanding levels than the teacher candidates studying in the other departments. When the understanding levels for the responses they gave to the other questions were evaluated, there was no difference between them with respect to their departments. When the understanding levels of the teacher candidates with respect to their departments were analysed, these teacher candidates were only at the same understanding level for the question related to the structure of the Moon. When the level of distribution for the other questions about the Moon was examined, it was revealed that the elementary science and physics teacher candidates were at higher understanding levels than the early childhood and primary school teacher candidates.

\section{Chi Square analysis between the departments}

The Chi-Square Test is done for each of the features of concepts and to determine whether there have been significant differences in understanding levels according to their department and the results are given in Table 12. 
Table 12. Chi-square test results about the relationship between candidates' department and understanding levels

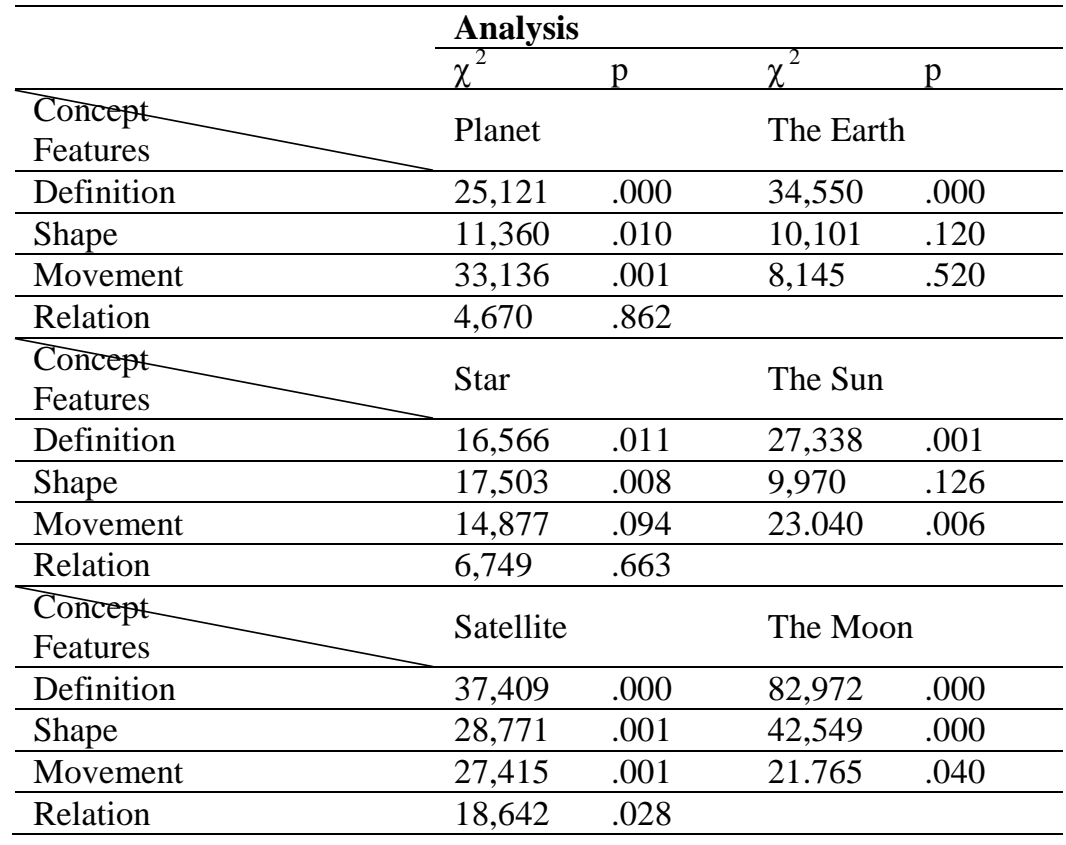

The results of Chi Square Test shows that there are differences in terms of departments for planet's definition $\left[\chi_{(6)}^{2}=25,121, p<0.05\right]$, shape $\left[\chi_{(3)}^{2}=11,360, p<0.05\right]$ and movement $\left[\chi^{2}\right.$ $\left.{ }_{(12)}=33,136, \mathrm{p}<0.05\right]$. For the Earth, there is difference between definition $\left[\chi^{2}{ }_{(9)}=34,550\right.$, $\mathrm{p}<0.05]$, but shape $\left[\chi_{(6)}^{2}=10,101, \mathrm{p}>0.05\right]$ and movement $\left[\chi_{(9)}^{2}=8,145, \mathrm{p}>0.05\right]$. Any significant difference wasn't found for the relationship between planet-the Earth in terms of departments $\left[\chi_{(9)}^{2}=4,670, p>0.05\right]$.

It can be seen in Table 13 that in terms of departments the significant differences for star's definition $\left[\chi_{(6)}^{2}=16,566, \mathrm{p}<0.05\right]$ and shape $\left[\chi^{2}{ }_{(6)}=17,503, \mathrm{p}<0.05\right]$, but movement $\left[\chi^{2}(9)=\right.$ $14,877, \mathrm{p}>0.05]$. For the Sun, while definition $\left[\chi^{2}{ }_{(9)}=27,338, \mathrm{p}<0.05\right]$ and movement $\left[\chi_{(9)}^{2}=\right.$ $23,040, \mathrm{p}<0.05]$ have significant differences, there is no significant difference for the shape $[\chi$ $\left.{ }_{(6)}=9,970, p>0.05\right]$. The relationship between star-the Sun in terms of departments isn't significant difference $\left[\chi_{(9)}^{2}=6,749, \mathrm{p}>0.05\right]$.

The Chi-Square Test results for each feature (definition, shape and structure) of satellite and moon were showed that there is a significant difference in terms of departments [satellite, $\chi$ ${ }_{\text {definition (9) }}=37,409, \mathrm{p}<0.05, \chi^{2}$ shape (9) $=28,771, \mathrm{p}<0.05, \chi^{2}$ movement (9) $=27,415, \mathrm{p}<0.05$; the Moon, $\chi^{2}$ definition (12) $=82,972, p<0.05, \chi^{2}$ shape (9) $=42,549, p<0.05, \chi^{2}$ movement (12) $=21.765$, $\mathrm{p}<0.05]$. The meaningful difference for relationship between satellite-the Moon is found $\left[\chi^{2}\right.$ $(9)=18,642, \mathrm{p}<0.05]$.

\section{Discussion and Conclusion}

The findings from this study reveal that the candidates have difficulty in answering questions related to basic astronomy concepts at a scientific understanding level. The results show similarities with the results of the studies carried out both with the teacher candidates and the teachers on this topic by different researchers (Barba \& Rubba, 1992; Summers \& Mant, 1995; Atwood \& Atwood, 1996, 1997; Zeilik, Mattern, Schau, Hall, Teague \& Bisard, 1997; Zeilik, Mattern \& Schau 1999; Trumper, 2001, 2006a, 2006b; Rutherford, 2004; 
Hudgins, 2005; Frede, 2006; Kalkan \& Kıroğlu, 2007; Küçüközer, 2007; Emrahoğlu \& Öztürk, 2009; İyibil \& Sağlam-Arslan, 2010).

The teacher candidates generally defined the Earth as the planet "where we live" and they could not make more scientific explanations. Similarly, in the study conducted by Barba and Rubba (1992), it was stated that the candidates lacked basic knowledge relating to the Earth. It was determined with the illustrations that the candidates thought that the Earth and 'the planet' only had a spherical shape but they did not emphasize the geoid shape of the Earth. In parallel with this finding, Sneider and Ohadi (1998), found the participants preferred the spherical shape among the choices presented to them for the shape of the Earth.

The participants who defined 'the star' as a celestial body which radiates the light it gets from various sources also appear in the studies conducted by Ünsal, Güneş and Ergin (2001), Emrahoğlu and Öztürk (2009) and İyibil and Sağlam-Arslan (2010). Similarly in the studies of Agan (2004) and Bailey (2006), the teacher candidates defined the Sun as a star. However, as Emrahoğlu and Öztürk (2009) and İyibil and Sağlam-Arslan (2010) pointed out in their studies; the participants explained that the Sun is a planet. Although there was no difference between the illustrations of the participants in terms of the departments, it can be stated that they had misconceptions which have been previously determined in the literature (İyibil \& Sağlam-Arslan, 2010) about the shape of the star. It can be stated that teacher candidates' illustrations resulted from the experiences they had had in their daily life (for example, the spherical illustration of the sun) and the reflections of our culture (for example, the illustration of the star as a pentagram on the Turkish flag).

Although the teacher candidates usually illustrated crescent, few teacher candidates drew the phases of the Moon instead of the shape of the Moon. The studies carried out in the literature were mostly interested in the phases of the Moon, they evaluated the developments in this field by applying the activities prepared to the participants, and an improvement was recorded in the levels of the participants. It was found that the individuals participating in these studies (Suzuki, 2003; Trundle et al., 2002, 2006, 2007; Mullholland \& Ginns, 2008) made more correct illustrations about the phases of the Moon and they could explain the reasons for the formation of the phases as a result of the activities.

In the literature, numerous studies have been carried out with the concepts of the Sun, the Earth, the Moon and their relationships. In addition, in this study, the relationships between the concept (i.e., 'planet') and examples of the concept (i.e., the Earth) were asked about in the questionnaire. Nevertheless, the teacher candidates were not able to establish relationships between astronomy concepts at an adequate level and they could not match the concept and examples of a concept (Also see, Table 13). Although most of the teacher candidates defined the Earth as a planet, it was found that they had different explanations for the concepts of the Earth and 'the planet'. Similarly, when the concepts of 'the star' and the Sun were taken into consideration, it was revealed that the candidates explained that the Sun was a star and they stated that the stars get their light from the Sun. Based on this point of view, it can be suggested that the teacher candidates did not acquire knowledge at a scientifically acceptable understanding level about basic astronomy concepts without taking into consideration the departments. In addition, we may consider the candidates' reasoning ability. Exemplarily, the Earth is a concrete example of the abstract concept of 'the planet'. Starting from this point, it would be expected that teacher candidates would make scientific explanations about the concept of a planet through the Earth. However, the teacher candidates barely explained the concept of 'the planet' and there was a difference between the understanding levels of the 
concept of 'the planet' and the Earth. Moreover, because the current situation has not been interfered with, the results obtained within the context of the study can be considered as an indicator that teacher candidates, so far, have not been able to actualize permanent learning as they could not structure how the information which was to be acquired was related to these concepts throughout the instruction they have received.

About the celestial motions in the daily life, Vosniadou and Brewer (1994) found that the children tried to explain day and night in terms of the sun going down behind the hills or being covered by clouds, or they gave explanations based on the notion that the sun revolves around the earth or the earth revolves around the sun or rotates around its axis. In addition, some studies found that children may explain the initial learning that the Sun - the Moon move up and down but not move across the sky (not moving through the horizontal direction) (Plummer, 2009, 2014; Plummer, Wasko, \& Slagle, 2011). Literature on children's ideas about the celestial motion indicated that children may have unscientifically knowledge. In this study, although teacher candidates could explain the movements of the Earth, the Sun and the Moon, they tried to explain planet, star and satellite movements unscientifically. It is seen that teacher candidates couldn't reason movements of the Earth, the Sun and the Moon through movements of planet, star and satellite.

It was found that the responses of early childhood and primary school teacher candidates were concentrated at understanding levels which contained less scientific knowledge than elementary science and physics teacher candidates. However, this statement does not mean that elementary science and physics teacher candidates gave scientific responses at higher rates, but generally the meaningful differences were found between the department and understanding level (See, Table 13). When the levels where the teacher candidates mainly concentrated with respect to their departments, and the reality that astronomy as a topic is a field of elementary science (in the natural sciences) is taken into consideration, it makes sense that the teacher candidates studying in this department will be more knowledgeable of the topic. This situation can be explained because of the interest of elementary science and physics teacher candidates in astronomy topics and also it makes us think that teacher candidates can make more scientific explanations due to the advantages of their fields of study and their numerical and spatial abilities.

The following suggestions can be made in the light of the findings obtained from the study. The teacher candidates' lack of knowledge about astronomy concepts, which are included in the teaching departments, make us think that they will have difficulties during the instruction of these topics in their future professional life. It can be estimated that these difficulties will lead to misconceptions and learning difficulties with the students. Therefore, the teacher candidates must be enabled to realize their deficiencies in the field they majored in and various opportunities about astronomy activities like finding the Sun and a star using Stellarium program, visiting planetarium must be given to the teacher candidates to remove these deficiencies and help them to develop themselves.

The teacher candidates' understanding levels related to the concepts which emerged in the study, and they're not being able to establish relationships at an adequate level between the concepts in the study, reveal that the teacher candidates either memorized the knowledge they acquired about the topic throughout their instruction or they learned superficially. Thus, the individuals must be enabled to learn basic concepts, such as astronomy concepts of the research, meaningfully and permanently throughout their educational life and learning must be a need because attaining the basic concepts plays an important role for the attainment of 
other concepts and topics. Therefore, it is suggested that a rich content and learning environment should be provided for the candidates to comprehend astronomy topics and concepts.

\section{References}

Abraham, M.R., Williamson, V.M. \& Westbrook, S.L. (1994). A cross age study of the understanding of five chemistry concepts. Journal of Research in Science Teaching, 31 (2), 147-165. Doi: 10.1002/tea.3660310206

Agan, L. (2004). Stellar ideas: Exploring students' understanding of stars. Astronomy Education Review, 3 (1), 77-97. Retrieved from: http://aer.aas.org/

Atwood, R.K. \& Atwood, V.A. (1996). Preservice elementary teachers' conceptions of the causes of seasons. Journal of Research in Science Teaching, 33 (5), 553-567. Doi: 10.1002/(SICI)10982736(199605)33:5<553::AID-TEA6>3.0.CO;2-Q

Atwood, R.K. \& Atwood, V.A. (1997). Effects of instruction on preservice elementary teachers' conceptions of the causes of night and day the seasons. Journal of Science Teacher Education, 8 (1), 1-13. Doi: 10.1023/A:1009455201314

Bailey, J. M. (2006). Development of a concept inventory to assess students' understanding and reasoning difficulties about the properties and formation of stars. ( $\mathrm{PhD}$ Thesis). The University of Arizona, USA.

Barba, R.H. \& Rubba, P.A. (1992). A comparison of preservice and in service Earth and Space science teachers' general mental abilities, content knowledge, and problem - solving skills. Journal of Research in Science Teaching, 29(10), 1021-1035. Doi: 10.1002/tea.3660291003

Callison, P.L. \& Wright, E.L. (1993, April). The effect of teaching strategies using models on preservice elementary teachers' conceptions about Earth-Sun-Moon relationships. Paper presented at the Annual Meeting of the National Association for Research in Science Teaching, Atlanta. Abstract retrieved from http://eric.ed.gov/?id=ED360171.

Cin, M. (2007). Alternative views of the solar system among Turkish students. Review of Education, 53, 39-53. Doi: 10.1007/s11159-006-9029-5

Cohen, L. \& Manion, L. (1994). Research methods in education. London, England: Routledge.

Çalık, M. \& Ayas, A. (2005). A comparison of level of understanding of eight - grade students and science student teachers related to selected chemistry concepts. Journal of Research in Science Teaching, 42 (6), 638- 667. Doi: 10.1002/tea.20076

Çepni, S. (2007). Araştırma ve proje çalışmalarına giriş [Introduction to Scientific Researches and Projects]. Trabzon: Celepler Matbaacilik.

Durukan, Ü.G. \& Sağlam-Arslan, A. (2013). Fen bilgisi öğretmen adaylarının temel astronomi kavramlarını ilişskilendirme durumlarının analizi. Fen Bilimleri Öğretimi Dergisi, 1(2), 97109. Retrieved from: http://fead.org.tr/dergi/

Emrahoğlu, N. \& Öztürk, A. (2009). Fen bilgisi öğretmen adaylarının astronomi kavramlarını anlama seviyelerinin ve kavram yanılgılarının incelenmesi üzerine boylamsal bir araştırma [A longitudinal research on the analysis of the prospective science teachers' level of understanding the astronomical concepts and their misconceptions]. Ç.U. Institute of Social Sciences, 18(1), 165-180. Retrieved from: http://dergipark.ulakbim.gov.tr/cusosbil/index

Ercan, F., Taşdere, A. \& Ercan, N. (2010). Kelime ilişkilendirme testi aracılığıyla bilişsel yapısı ve kavramsal değişimin gözlenmesi [Observation of cognitive structure and conceptual changes through word associations tests]. Journal of Turkish Science Education, 7(2), 136-153. Retrieved from: http://www.tused.org/

Erden, M. (2005). Öğretmenlik meslĕgine giriş [Introduction to Teaching Profession]. İstanbul: Epsilon Yayıncilık.

Frede, V. (2006). Pre-Service elementary teacher's conceptions about astronomy. Advances in Space Research, 38, 2237-2246. Doi: 10.1016/j.asr.2006.02.017 
Hudgins, D.W. (2005). Investigation of the effect of ranking tasks on student understanding of key astronomy topics. (PhD thesis). The University of South Africa, South Africa.

İyibil, Ü.G. \& Sağlam-Arslan, A. (2010). Fizik öğretmen adaylarının yıldız kavramına dair zihinsel modelleri [Pre-service physics teachers' mental models about stars]. Necatibey Faculty of Education Electronic Journal of Science and Mathematics Education, 4(2), 25-46. Retrieved from: http://dergipark.ulakbim.gov.tr/balikesirnef/index

Kalkan, H. \& Kıroğlu, K. (2007). Science and nonscience students' ideas about basic astronomy concepts in preservice training for elementary school teachers. Astronomy Education Review, 6(1), 15-24. Retrieved from: http://aer.aas.org/

Kallery, M. (2011). Astronomical concepts and events awareness for young children. International Journal of Science Education, 33(3), 341-369. Doi: 10.1080/09500690903469082

Kara, İ., Erduran-Avcı, D. \& Çekbaş, Y. (2008). Fen bilgisi öğretmen adaylarının 1şık kavramı ile ilgili bilgi düzeylerinin araştırılması [Investigation of the science teacher candidates' knowledge level about the concept of light]. M.A.E.U. Journal of Education Faculty, 8(16), 46-57. Retrieved from: http://edergi.mehmetakif.edu.tr/index.php/efd

Karal, I.S. (2003). Fizik ögretmeni adaylarının konu alanı bilgi düzeylerinin belirlenmesi [Determination on subject matter knowledge level of physics teacher candidates]. (Master Thesis). Karadeniz Teknik Üniversitesi, Trabzon.

Karasar, N. (2009). Bilimsel araştırma yöntemi [Scientific research method]. Ankara: Nobel Yayın Dağıtım.

Kikas, E. (2005). Development of children's knowledge: the sky, the Earth and the Sun in children's explanations. Electronic Journal of Folklore, 31, 31- 56. Retrieved form: http://www.folklore.ee/folklore

Klein, C.A. (1982). Children's concepts of the Earth and the Sun: A cross cultural study. Science Education, 65 (1), 95-107. Doi: 10.1002/sce.3730660112

Kurnaz, M.A. (2012). Yıldız, kuyruklu yıldız ve takımyıldız kavramlarıyla ilgili öğrenci algilamalarının belirlenmesi [Determining students' comprehension of the star, comet, and constellation concepts]. A.I.B.U. Education Faculty Journal, 12(1), 251-264. Retrieved from: http://efdergi.ibu.edu.tr/index.php/efdergi

Küçüközer, H. (2007). Prospective science teachers' conceptions about astronomical subjects. Science Educational International, 18(2), 113-130. Retrieved from: http://www.icaseonline.net/seiweb/

Küçüközer, H., Bostan, A. \& Işıldak, R.S. (2010). İlköğretim matematik öğretmeni adaylarının bazı astronomi kavramlarına ilişkin fikirlerine öğretimin etkileri [Effects of instruction on preservice mathematics teachers' ideas about some astronomy concepts]. OMÜ Ĕ̈itim Fakültesi Dergisi, 29(1), 105-124. Retrieved from: http://dergipark.ulakbim.gov.tr/omuefd/

Liu, S.H. (2003). Models of "The Heavens and the Earth": an investigation of German and Taiwanese students' alternative conceptions of the universe. International Journal of Science and Mathematics Education, 3, 295-325. Doi: 10.1007/s10763-004-4032-4

Liu, O.L., Lee, H.S, Hofstetter, C. \& Linn, M.C. (2008). Assessing knowledge integration in science: Construct measures and evidence. Educational Assessment, 13, 33-55. Doi: $10.1080 / 10627190801968224$

M.E.B. (2005). Illköğretim fen ve teknoloji dersi (4 ve 5. sinıflar) ögretim programı. Talim ve Terbiye Kurulu Başkanlığ1, Ankara. Retrieved from: ttkb.meb.gov.tr/program2.aspx

M.E.B. (2006). Illköğretim fen ve teknoloji dersi (6, 7 ve 8. siniflar) öğretim programı. Talim ve Terbiye Kurulu Başkanlığı, Ankara. Retrieved from: ttkb.meb.gov.tr/program2.aspx

M.E.B. (2009). İlköğretim 1, 2 ve 3. sinıflar hayat bilgisi dersi öğretim programı ve kılavuzu. Talim ve Terbiye Kurulu Başkanlığı, Ankara. Retrieved from: ttkb.meb.gov.tr/program2.aspx

Mullholland, J. \& Ginns, I. (2008). College Moon project Australia: Preservice teachers learning about the Moon's phases. Research Science Education, 38, 385-399. Doi: 10.1007/s11165-0079055-8 
Panagiotaki, G., Nobes, G. \& Potton, A. (2009). Mental models and other misconceptions in children's understanding of the Earth. Journal of Experimental Child Psychology, 104(1), 5267. Doi: 10.1016/j.jecp.2008.10.003

Percy, J.R. (1998). Variable stars in astronomical research, education, and development. Astrophysics and Space Science, 258, 357-365. Doi: 10.1023/A:1001772315586

Plummer, J.D. (2009). A cross-age study of children's knowledge of apparent celestial motion. International Journal of Science Education, 31, 1571-1605. Doi: $10.1080 / 09500690802126635$

Plummer, J.D., Wasko, K.D. \& Slagle, C. (2011). Children learning to explain daily celestial motion: Understanding astronomy across moving frames of reference. International Journal of Science Education, 33 (14), 1963-1992. Doi: 10.1080/09500693.2010.537707

Plummer, J.D. (2014). Spatial thinking as the dimension of progress in an astronomy learning progression. Studies in Science Education, 50 (1), 1-45. Doi: 10.1080/03057267.2013.869039

Rutherford, I.B. (2004). Exploring alternative conceptions of teachers and informal educators about selected astronomy concepts. (PhD Thesis). The University of Cincinnati, USA.

Sağlam-Arslan, A. \& Kurnaz, M.A. (2009). Prospective physics teachers' level of understanding energy, power and force concepts. Asia-Pasific Forum on Science Learning and Teaching, 10, 1-18. Retrieved from: http://www.ied.edu.hk/apfslt

Sneider, C.I. \& Ohadi, M.M. (1998). Unraveling students' misconceptions about the Earth's shape and gravity. Science Education, 82, 265- 284. Doi: 10.1002/(SICI)1098237X(199804)82:2<265::AID-SCE8>3.0.CO;2-C

Straatemeier, M., Van der Mass, H.L.J. \& Jansen, B.R.J. (2008). Children's knowledge of the Earth: a new methodological and statistical approach. Journal of. Experimental Child Psychology,100, 276-296. Doi: 10.1016/j.jecp.2008.03.004

Summers, M. \& Mant, J. (1995). A survey of British primary school teachers' understanding of the Earth's place in the universe. Educational Research, 37(1), 3-19. Doi: $10.1080 / 0013188950370101$

Suzuki, M. (2003). Conversations about the Moon with prospective teachers in Japan. Science Education, 87(6), 892-910. Doi: 10.1002/sce.10082

Şahin, Ç., Bülbül, E. \& Durukan, Ü.G. (2013). The effect of conceptual change texts on removing students' alternative conceptions about celestial bodies. Journal of Computer and Educational Research, 1(2), 38-64. Retrieved from: http://dergipark.ulakbim.gov.tr/jcer

Taşcan, M. (2013). Fen bilgisi ögretmenlerinin temel astronomi konularındaki bilgi düzeylerinin belirlenmesi (Malatya İli Örneği) [Determine of science teachers knowledge level about basic astronomy subjects (The example of Malatya)]. (Yüksek Lisans Tezi). İnönü Üniversitesi, Malatya.

Trumper, R. (2001). A cross- college age study of science and nonscience students' conceptions of basic astronomy concepts in preservice training for high-school teachers. Journal of Science Education and Technology, 10 (2), 189-195. Doi: 10.1023/A:1009477316035

Trumper, R. (2006a). Teaching future teachers basic astronomy concepts- sun- earth- moon relative movements-at a time of reform in science education. Research in Science and Technological Education, 24(1), 85-109. Doi: 10.1080/02635140500485407

Trumper, R. (2006b). Teaching future teachers basic astronomy concepts-seasonal changes- at a time reform in science teaching. Journal of Research in Science Teaching, 43(9), 879-906. Doi: 10.1002/tea.20138

Trundle, K.C., Atwood, R.K. \& Christopher, J.E. (2002). Preservice elementary teachers' conceptions of Moon phases before and after instruction. Journal of Research in Science Teaching, 39(7), 633-658. Doi: 10.1002/tea.10039

Trundle, K.C., Atwood, R.K. \& Christopher, J.E. (2006). Preservice elementary teachers' knowledge of observable Moon phases and pattern of change in phases. Journal of Science Teacher Education, 17, 87-101. Doi: 10.1007/s10972-006-9006-7

Trundle, K.C., Atwood, R.K. \& Christopher, J.E. (2007). A longitudinal study of conceptual change: Preservice elementary teachers' conceptions of Moon phases. Journal of Research in Science Teaching, 44(2), 303- 326. Doi: 10.1002/tea.20121 
Tunca, Z. (2005, September). Türkiye'de ilk ve ortaöğretimde astronomi eğitim ve ögretiminin dünü, bugünü. Paper presented at the Ulusal 5. Fen Bilimleri ve Matematik Eğitimi Kongresi, Ankara. Abstract retrieved from www.fedu.metu.edu.tr/UFBMEK5/b_kitabi/PDF/Astronomi/Panel/ t1-3d.pdf

Türkoğlu, O., Örnek, F., Gökdere, M., Süleymanoğlu, N. \& Orbay, M. (2009). On pre-service science teachers' preexisting knowledge levels about basic astronomy concepts. International Journal of Physical Sciences, 4(11), 734-739. Retrieved from: http://www.academicjournals.org/ijps

Uzunkavak, M. (2009). Öğrencilerin Newton kanunları bilgilerinin yazı ve çizim metoduyla karşılaştırılması [Comparison of students' knowledge about Newton's laws by writing and drawing metod]. SDU International Journal of Technologic Sciences, 1(1), 29-40. Retrieved from: http://edergi.sdu.edu.tr/index.php/utbd

Ünsal, Y., Güneş, B. \& Ergin, İ. (2001). Yükseköğretim öğrencilerinin temel astronomi konularındaki bilgi düzeylerinin tespitine yönelik bir araştırma [ A study of investigate the fundamental astronomy knowledge levels of undergraduate students]. G.U. Journal of Gazi Educational Faculty, 21(3), 47-60. Retrieved from: http://www.gefad.gazi.edu.tr

Wallace, C.S., Prather, E.E. \& Duncan, D.K. (2011). "A Study of General Education Astronomy Students' Understandings of Cosmology. Part I. Development and Validation of Four Conceptual Cosmology Surveys". Astronomy Education Review, 10, 010106. Retrieved from: http://aer.aas.org/

Wallace, C.S., Prather, E.E. \& Duncan, D.K. (2012). A study of general education astronomy students' understandings of cosmology. Part V. The effects of a new suite of cosmology lecture-tutorials on students' conceptual knowledge. International Journal of Science Education, 34(9), 1297-1314. Doi: 10.1080/09500693.2012.677960

Zeilik, M., Mattern, N., Schau, C., Hall, S., Teague, K.W. \& Bisard,W. (1997). Conceptual astronomy: A novel model for teaching post secondary science courses. American Journal of Physics, 65 (10), 987-996. Doi: 10.1119/1.18702

Zeilik, M., Mattern, N. \& Schau, C. (1999). Conceptual astronomy II. Replicating conceptual gains, probing attitude changes across three semesters. American Journal of Physics, 67(10), 923927. Doi: $10.1119 / 1.19151$ 